2020, Volume 14, International Conference Innovative Business Management \& Global Entrepreneurship (IBMAGE 2020), pages: 436-449 |

https://doi.org/10.18662/lumproc/ibmage2020/32

\section{Romanian Forest Sector Labor Force - Evolutions and Trends}

\section{Laurențiu CIORNEI1, Paula MUNTEANU2*}

${ }^{1}$ Center for Study and Research for AgroForestry Biodiversity "Acad. David Davidescu", Romanian Academy, Bucharest, Romania, laurentiu.ciornei@ince.ro

${ }^{2}$ School of Advanced Studies of the Romanian Academy (SCOSAAR), Romanian Academy, Bucharest, Romania,pma.munteanu@gmail.com

* Corresponding Author
Abstract: As a trend of evolution, the labor force in the Romanian forestry sector is part of trajectory registered by the European Union, as a whole, because many of the member countries are still oriented on the traditional methods of administration, harvesting and processing. However, there are also developed countries with large forested areas (Finland, Sweden) that have embraced new technologies and adjusted management and production processes. This issue aimed, among other things, at reducing the number of people employed in the forestry sector.

In Romania, increasing the number of the employees, based on the quantitative increase of jobs as result of the gross exploitation of resources, will slow down by adopting new technologies, reducing the consumption of natural resources, but also as an effect of economic shocks generated by the pandemic. For these reasons, according to our study, the low-skilled workforce will suffer, this being the most vulnerable category, as technological developments need employees with higher skills and abilities. Equally, the informal sector must be taken into account because it employs four times people more.

Romania have to adopt those appropriate measures in order to help the incorporation of the labor force released from the forestry sector of resource exploitation into adjacent sustainable activities.

Keywords: Forest sector; sustainable development; labor force; new technologies.

How to cite: Ciornei, L., \& Munteanu, P. (2020). Romanian Forest Sector Labor Force - Evolutions and Trends. In M. W. Staniewski, V. Vasile, \& A. Grigorescu (vol. ed.), Lumen Proceedings: Vol. 14. International Conference Innovative Business Management \& Global Entrepreneurship (IBMAGE 2020) (pp. 436-449). Iasi, Romania: LUMEN Publishing House. https://doi.org/10.18662/lumproc/ibmage2020/32 


\section{Introduction}

Sustainable and sustained timber production, combined with industrial efficiency, would increase the forest sector revenues and provide long-term stability. Internationally, it is confirmed that this sector could contribute to national economic growth, employment and well-being [10]. However, this sector cannot evolve differently from the trends that manifest itself globally and at European level, because "international environmental governance is increasingly influencing the decision-making process [...]" [14].

In this context, Romania must be part of the international and European trajectory and this aspect can only be achieved through a good collaboration between all relevant factors. Results must lead to the sustainable development of the Romanian forestry sector, in general, and of human resources, in particular.

\section{Problem Statement}

According to Global Forest Resources Assessment [5], globally, 1.15 billion hectares of forest (approximately 30\%) are mainly managed for the production of wood and non-timber (complementary) forest products, which provide about $20 \%$ of incomes of rural households in developing countries with access to forest resources [2]. The forestry sector creates about 45 million jobs globally, and revenues amount to about 580 billion USD, annually [4]. Almost $50 \%$ of jobs are generated by small and mediumsized enterprises, generating more than 130 billion USD, annually. Given that a large part of the forestry sector is in the informal economy, not covered by national statistics, the real figures may be much higher. The informal forest economy is estimated to generate approximately 124 billion USD, annually, providing employment for another nearly 41 million people [3]. Indigenous peoples are largely dependent on forest resources [7].

At the end of 2019, globally, more than a third of people depend on forest and forest products. However, the heterogeneity of people's interactions with forests makes it difficult to define forest dependence in a standardized and meaningful way [12]. Biodiversity provides food, energy and income, limited by seasonal fluctuations and extreme events [13]. Also, for many rural communities, forests provide consistent income as a result of tourism [8]. Overall, the forest economy, formal or informal, encompasses a significant portion of the world's population and provides significant income and resources for life. 
At European level, the forestry sector is the third largest employer, with over 3.5 million of employed people. However, the European Union has a number of particularities generated mainly by the depopulation of rural areas, the loss of employment, structural changes in society, the fragmentation and abandonment of private forest properties. In order to achieve the goals of sustainable development, it was created Forest Europe [6], a political process for dialogue and cooperation in forest policy in Europe. A major concern of Forest Europe is labor force development and its integration into sustainable forest management. In this sense, the objectives are oriented towards the formation of a qualified and adaptable labor force, in which education and training play an important role.

The preparation of human resources must be focused on training for green jobs and fulfilling increasingly complex tasks generated by new technologies.

\section{Research Questions/Aims of the research}

In this context, the main objective of this study is to anticipate the evolution that Romania will register in the next period, from the perspective of the number of people employed in the forestry sector. We start from the hypothesis that modern methods of exploitation and management, as well as the reduction of the gross exploitation of forest resources will lead to the decrease of jobs in this sector. The adoption of new technologies and economic shocks generated by the pandemic will accelerate this process. Romania cannot leave the international and European trajectory, taking into account the progress registered by certain countries in this sector of activity. By streamlining the forestry sector, part of the current workforce will be disposed and have to be incorporated into other areas and sectors of activity, this issue requiring good cooperation between policy makers, public institutions, forest owners, forest managers, workforce, various professionals and entrepreneurs.

\section{Research Methods}

In order to achieve the main objective of this study, we performed a comparative analysis of the forestry labor force, at the level of the European Union member countries, for the period of time between 2010-2019, taking into account some of the most representative indicators.

Obviously, the analysis of the labor market and the labor force is a broad and laborious one, but it goes beyond the proposed scope of research. 
We deepened the study by comparing the statistical data of the stateowned company Romsilva RA with those of a similar company in Finland, Metsähallitus.

Based on these data, we formulated conclusions regarding the labor force in the Romanian forestry sector. This confirms the basic hypothesis that modern methods of exploitation and management, as well as the reduction of gross exploitation of forest resources will lead to a decrease in jobs in this sector, and decision makers must be prepared with solutions for the incorporation of disposed labor force into other areas and sectors of activity, according with the sustainable development principles.

According to most studies, the lower-trained workforce is the most vulnerable, being the first category to be affected when we talk about new technologies, because technological developments need people with higher skills and abilities. Overall, the social factor will suffer, especially since it also includes the informal sector, which has not been sufficiently and thoroughly researched.

\section{Findings}

The forestry sector is predominantly a male field one [1], but global trends are aimed at increasingly including women in all sectors of activity. Current male culture is associated with a higher risk area, few studies and low earnings.

Table 1. Employment in the forestry sector 2019 - men (thousands of people)

$\begin{array}{lcccccccccc}\text { Belgium } & 39,6 & 34,6 & 33 & 28,1 & 31,3 & 31,4 & 30,1 & 34,1 & 33,9 & 28,2 \\ \text { Bulgaria } & 60,8 & 54,4 & 55,9 & 54,2 & 55,2 & 56,6 & 58,8 & 60,1 & 53,3 & 51,5 \\ \text { Czech } & & & & & & & & & & \\ \text { Republic } & 75,7 & 79,1 & 72,7 & 70,2 & 71,4 & 76,1 & 72,2 & 73,6 & 79,9 & 72 \\ \text { Denmark } & 18,9 & 20,7 & 19,4 & 17,4 & 17,2 & 16,2 & 17,2 & 14,8 & 20,6 & 18,6 \\ \text { Germany } & 303,8 & 298,6 & 296,6 & 271,1 & 274,2 & 269,8 & 272,9 & 261,1 & 261,3 & 261,9 \\ \text { Estonia } & 19 & 19,9 & 21,3 & 21,9 & 23,4 & 24,3 & 22,2 & 20,7 & 21,7 & 21,2 \\ \text { Ireland } & 9,9 & 8,4 & 4,9 & 7,3 & 4,8 & 5,7 & 8,5 & 11,4 & 6,6 & 6,7 \\ \text { Greece } & 33,7 & 29,6 & 20,3 & 15,2 & 15,2 & 15,3 & 13,5 & 18,2 & 19,9 & 20,5 \\ \text { Spain } & 169,2 & 162,8 & 136,6 & 130,9 & 135,2 & 149,2 & 144,7 & 160,2 & 158,4 & 161,2 \\ \text { France } & 153,2 & 150,2 & 158,3 & 166,2 & 151,2 & 148,5 & 151,1 & 145,7 & 143,5 & 134,2\end{array}$




\begin{tabular}{lcccccccccc} 
& 2010 & 2011 & 2012 & 2013 & 2014 & 2015 & 2016 & 2017 & 2018 & 2019 \\
\hline Croatia & 34,5 & 36,4 & 39,7 & 36,7 & 34,6 & 35,6 & 43,5 & 36,9 & 36,3 & 40,7 \\
Italy & 262,6 & 275,8 & 253 & 258,1 & 276,6 & 262,5 & 264,4 & 264 & 263,7 & 276,1 \\
Cyprus & 2,1 & 3,6 & 3,5 & 2,1 & 1,6 & 2 & 1,9 & 1,6 & 3 & 2,6 \\
Latvia & 31,2 & 30,7 & 33,5 & 37,6 & 33,7 & 31,2 & 29,1 & 30,5 & 32,4 & 32,5 \\
Lithuania & 35,2 & 37,6 & 40,3 & 41,5 & 41,8 & 41,4 & 41,3 & 41,6 & 39,9 & 40,4 \\
Luxembourg & 0 & 0 & 0 & 0 & 0 & 0 & 0 & 0 & 0 & 0 \\
Hungary & 48,7 & 52,7 & 52,5 & 54,4 & 59,9 & 54,8 & 52,6 & 61,7 & 63,6 & 61,2 \\
Malta & 1,2 & 1,1 & 1 & 0,9 & 0,9 & 0,7 & 0,7 & 0,9 & 1,2 & 0,8 \\
Netherlands & 44 & 38,5 & 35,9 & 34,5 & 36 & 36,6 & 35,9 & 37 & 36,3 & 34,3 \\
Austria & 53,7 & 51,2 & 56,7 & 57,5 & 56,7 & 55,3 & 53,3 & 57,5 & 59,2 & 60,3 \\
Poland & 344,4 & 346,2 & 350,4 & 354,1 & 361,3 & 358,5 & 367,7 & 409,4 & 417,8 & 372,7 \\
Portugal & 69,9 & 67,8 & 64,9 & 58,8 & 68,2 & 75 & 72 & 74,8 & 74,3 & 70,6 \\
Romania & $\mathbf{1 4 7}$ & $\mathbf{1 5 7 , 6}$ & $\mathbf{1 7 1 , 8}$ & $\mathbf{1 7 6 , 7}$ & $\mathbf{1 8 2}$ & $\mathbf{1 6 0 , 5}$ & $\mathbf{1 6 9 , 4}$ & $\mathbf{1 6 7 , 4}$ & $\mathbf{1 6 3 , 6}$ & $\mathbf{1 6 8 , 1}$ \\
Slovenia & 21,8 & 20,5 & 20,6 & 16,9 & 16,9 & 16,1 & 15,7 & 15,9 & 17 & 15,1 \\
Slovakia & 44,3 & 41,4 & $\mathbf{4 2 , 1}$ & 37,2 & 41,6 & 40,7 & 43 & 41,5 & 38,8 & 45,5 \\
Finland & 52,5 & 54,5 & 49,5 & $\mathbf{4 7 , 6}$ & $\mathbf{4 7 , 6}$ & $\mathbf{4 7 , 8}$ & 46 & 43,8 & 47,3 & 47,7 \\
Sweden & 71,7 & $\mathbf{7 2 , 9}$ & $\mathbf{6 7 , 4}$ & $\mathbf{6 5 , 4}$ & $\mathbf{6 5 , 4}$ & $\mathbf{6 4 , 6}$ & $\mathbf{6 2 , 6}$ & $\mathbf{6 1 , 9}$ & $\mathbf{6 1 , 7}$ & $\mathbf{6 2 , 4}$ \\
\hline
\end{tabular}

Source: Authors selection and reprezentation with data from Eurostat, 2019

In Romania, $22 \%$ of the forestry workforce is female, similar to the European Union average of $22.6 \%$. The largest share of women is in the furniture and woodworking industry, and the lowest is in forestry and logging where raw labor continues to be provided by men.

Regarding the level of training, high school and post-high school education is predominant in the forestry sector (Figure 1). In Belgium, Ireland, Slovakia and Finland, the workforce involves only high school, postsecondary and university studies. In Portugal, the share of low-educated workers is highest.

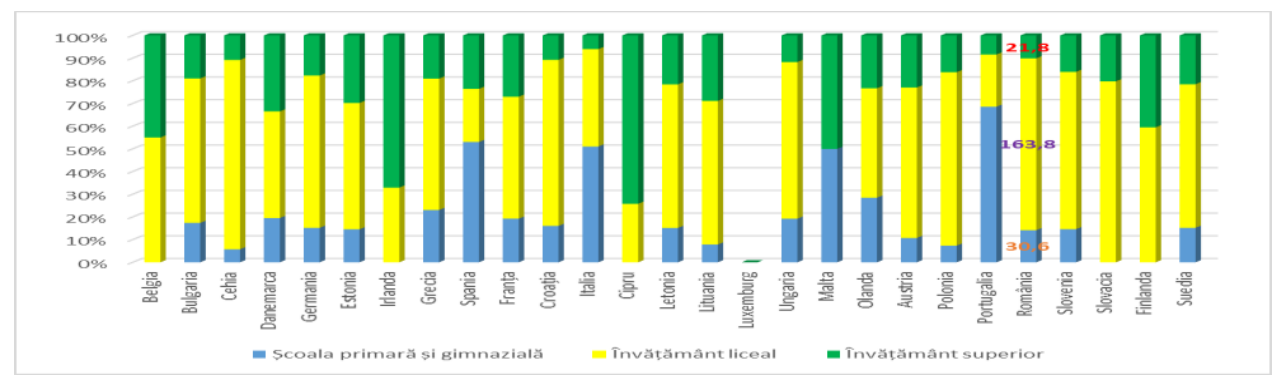




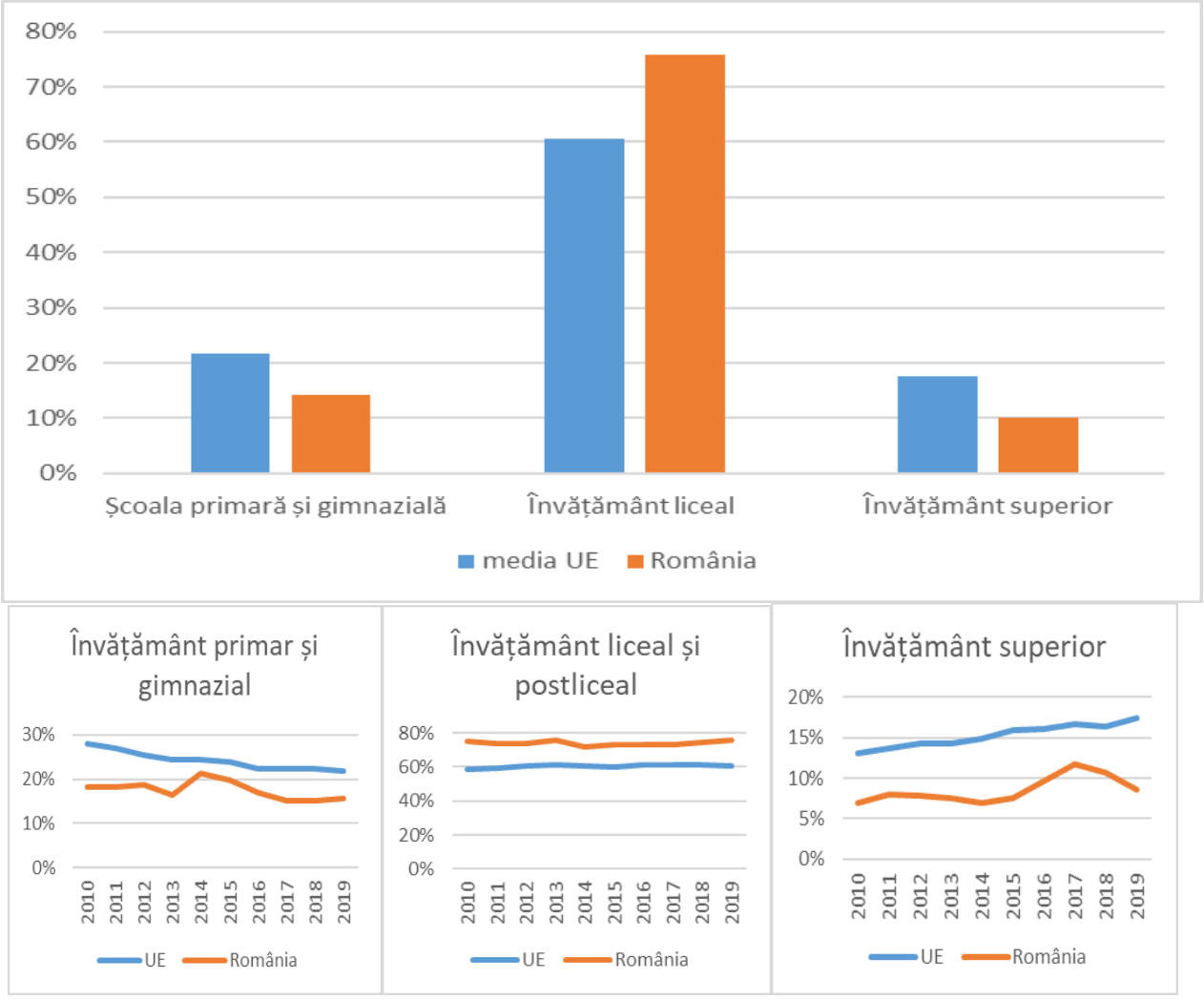

Figure 1. Forest sector workforce - education levels - 2019

Source: Authors reprezentation

In Romania, high school studies are predominant, being above the European Union average, primary and higher education being below the European average.

Table 2. Employment in the forestry sector in Romania - levels of education (thousands of people), 2019

\begin{tabular}{|c|c|c|c|c|c|c|c|c|c|c|c|c|}
\hline \multirow{2}{*}{ An } & \multicolumn{3}{|c|}{$\begin{array}{l}\text { Silvicultură și exploatare } \\
\text { forestieră }\end{array}$} & \multicolumn{3}{|c|}{$\begin{array}{l}\text { Fabricarea lemnului și a produselor } \\
\text { din lemn (cu exceptia mobilierului) }\end{array}$} & \multicolumn{3}{|c|}{$\begin{array}{l}\text { Fabricarea hârtiei și a } \\
\text { produselor din hârtie }\end{array}$} & \multicolumn{3}{|c|}{ Fabricarea mobilei } \\
\hline & $\begin{array}{c}\text { Primară } \\
/ \\
\text { gimnazi } \\
\text { ală }\end{array}$ & Liceu & Superior & $\begin{array}{c}\text { Primară } \\
\text { gimnazi } \\
\text { ală }\end{array}$ & Licen & Superior & $\begin{array}{c}\text { Primară } \\
\substack{/ \\
\text { gimnazi } \\
\text { ală }} \\
\end{array}$ & Liceu & Superior & $\begin{array}{l}\text { Primară } \\
\text { gimnazi } \\
\text { ală }\end{array}$ & Liceu & Superion \\
\hline 2010 & 8,4 & 25,9 & 4,7 & 13,8 & 42,8 & 2,7 & 2,6 & 8,8 & $0, \hat{3}$ & 11,7 & 72,0 & 6,1 \\
\hline 2011 & 8,7 & 26,3 & 6,1 & 15,1 & 44,8 & 2,7 & 1,3 & 7,1 & 0,1 & 12,4 & 74,3 & 7,4 \\
\hline 2012 & 10,9 & 30,3 & 8,4 & 15,2 & 47,0 & 3,4 & 2,5 & 7,1 & 0,3 & 12,1 & 75,8 & 4,9 \\
\hline 2013 & 9,2 & 29,5 & 8,6 & 12,8 & 51,8 & 2,8 & 2,4 & 8,2 & 0,3 & 12,3 & 80,6 & 5,2 \\
\hline 2014 & 9,4 & 26,2 & 7,6 & 15,5 & 57,0 & 2,8 & 4,1 & 6,5 & 0,5 & 19,7 & 73,9 & 4,9 \\
\hline 2015 & 7,5 & 22,7 & 7,0 & 16,9 & 50,2 & 3,5 & 3,0 & 6,6 & 0,3 & 12,9 & 69,4 & 4,4 \\
\hline 2016 & 7,2 & 20,9 & 10,0 & 15,9 & 51,2 & 5,4 & 1,4 & 6,7 & 0,2 & 12,2 & 79,6 & 5,1 \\
\hline 2017 & 7,2 & 19,2 & 16,0 & 11,9 & 50,7 & 5,4 & 1,5 & 6,7 & 0,2 & 14,0 & 91,3 & 5,3 \\
\hline 2018 & 7,2 & 21,7 & 14,0 & 12,5 & 49,6 & 3,6 & 2,3 & 8,3 & 0,3 & 11,7 & 86,8 & 6,0 \\
\hline 2019 & 6,7 & 28,7 & 8,7 & 13,2 & 47,9 & 4,7 & 3,3 & 9,4 & 0,4 & 10,7 & 77,8 & 4,7 \\
\hline
\end{tabular}

Source: Authors' processing based on Eurostat data 
In the past, forest inventory was laborious and often inaccurate one. Keeping the inventory up to date was expensive, the cause for incomplete statistics and often with large errors. The forester used several elements necessary for the profession: a compass, a map, an instrument for measuring the circumference of the trees, paper and pencil. In addition, he was trained to walk many kilometers every day and go through the thickets of virgin forests to find trees and estimate volume.

Currently, as a result of new technologies, the inventory is up-to-date and secure, with low administration costs. In modern inventory, the geographic information system (GIS) is basic and helps not only the inventory itself, but also the collection of information. The software is constantly evolving.

All these developments are slowly changing the face of the forestry sector. Moreover, it is the workforce that will be directly affected. An increasingly skilled workforce is needed. Working with new technologies requires higher and higher skills. This will deepen social inequalities as a result of rising incomes of the skilled employees, to the detriment of the many disposed unskilled peoples.

With regard to the manufacturing industry, new technologies are gaining ground in the face of unskilled or environmentally skilled labor.

Regarding the evolution of the labor force in the Romanian forestry sector, it does not differ much from the European average, which means that the impact of countries based on old technologies and exploitation concepts is still strong (Figure 1). However, there are also countries within the European Union that enjoy new technologies and modern methods of exploitation and production. This is evident only by analyzing the ratio of forested area to the size of the forestry and logging workforce (Table 3).

Table 3. Area occupied by forests (thousand ha) and the number of employees in forestry and logging, 2019

\begin{tabular}{lccc}
\multicolumn{1}{c}{ Country } & Forest area (thousand ha) & $\begin{array}{c}\text { Forestry and logging } \\
\text { employees (thousands) }\end{array}$ & ha / employee \\
\hline Sweden & $30.505,00$ & 11,9 & $2.563,45$ \\
Spain & $27.626,65$ & 23 & $1.201,16$ \\
Finland & $23.019,00$ & 14,1 & $1.632,55$ \\
France & $17.579,00$ & 22,5 & 781,29 \\
Germany & $11.419,00$ & 26,7 & 427,68 \\
Italy & $11.110,00$ & 43 & 258,37 \\
Poland & $9.435,00$ & 51,3 & 183,92
\end{tabular}




\begin{tabular}{lccr} 
Country & Forest area (thousand ha) & $\begin{array}{c}\text { Forestry and logging } \\
\text { employees (thousands) }\end{array}$ & ha / employee \\
\hline Romania & $\mathbf{6 . 9 5 1 , 0 0}$ & $\mathbf{4 4 , 1}$ & $\mathbf{1 5 7 , 6 2}$ \\
Greece & $6.539,00$ & 5 & $1.307,80$ \\
Portugal & $4.907,21$ & 9,3 & 527,66 \\
Austria & $4.022,00$ & 9,4 & 427,87 \\
Bulgaria & $3.845,00$ & 23,3 & 165,02 \\
Latvia & $3.468,00$ & 16,1 & 215,40 \\
Czech & $2.667,41$ & 14,3 & 186,53 \\
Republic & $2.491,00$ & 12,6 & 197,70 \\
Croatia & $2.455,51$ & 5,8 & 423,36 \\
Estonia & $2.284,00$ & 10,1 & 226,14 \\
Lithuania & $2.190,43$ & 16,1 & 136,05 \\
Hungary & $1.940,00$ & 9,8 & 197,96 \\
Slovakia & $1.271,00$ & 1,6 & 794,38 \\
Slovenia & 657,69 & 3,5 & 187,91 \\
Denmark & 386,19 & 0,9 & 429,10 \\
Cyprus & & &
\end{tabular}

Source: Authors' processing based on Eurostat data

We note that in developed EU countries, such as Sweden, Finland and Spain, which enjoy large areas of forest, the size of the forest management and logging workforce is significantly reduced compared to the labor force involved in the countries of the former communist bloc. The Swedes manage to cover over 2,500 ha of forest with a single employee, while the Hungarians cover only 136 hectares of forest. 

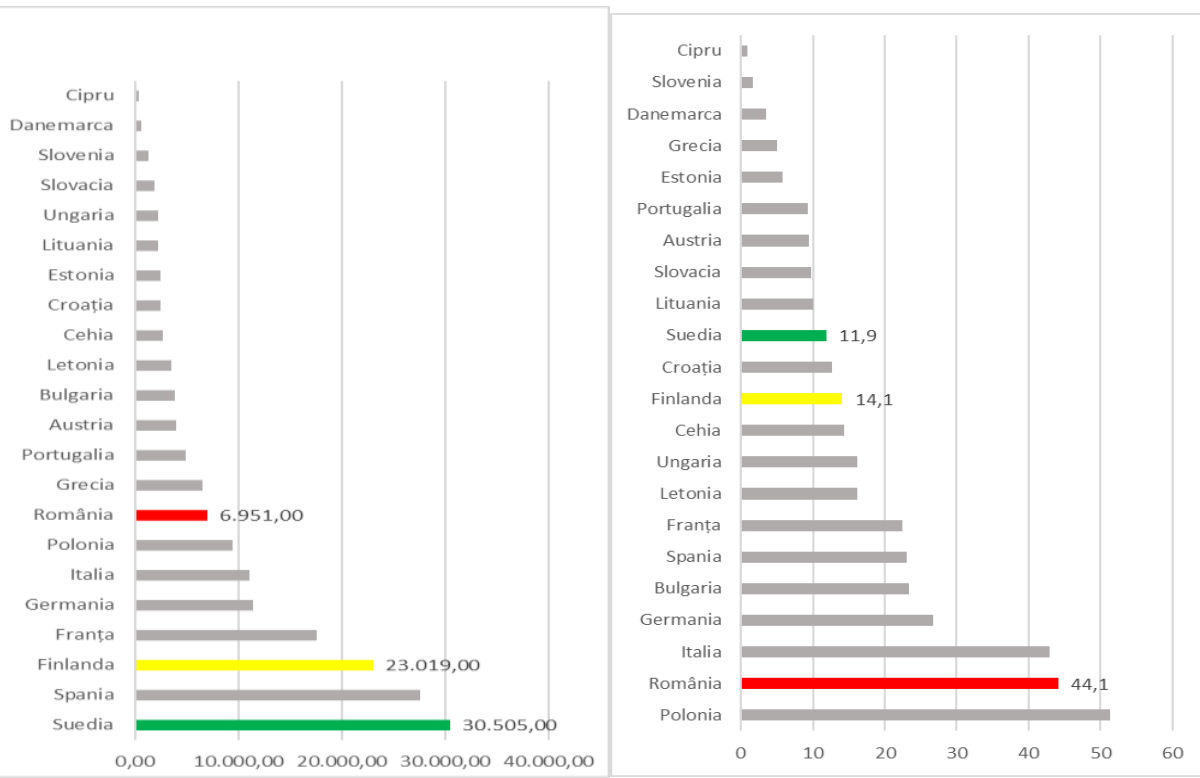

Figure 2. Area occupied by forests - left (thousand hectares), 2019 - Employment in forestry and logging - right (thousand people), 2019

Source: Author representation based on Eurostat data

Depending on the forested area, Romania ranks 8th in the European Union, but in terms of number of forestry and forestry workers, Romania ranks 2nd, with over 44,000 people involved. Sweden has the largest forested area, almost five times larger compared to Romania, and the employed labor force is four times smaller than that involved in Romania, in forestry activities.

Table 4. Logging (thousand cubic meters) depending on the form of ownership over the forests

Other public

\begin{tabular}{cccc} 
Country & State property & entities & Private property \\
\hline Belgium & - & - & - \\
Bulgaria & $4.869,33$ & 745,79 & 840,89 \\
Czech & & & \\
Republic & 13.032 & 4.321 & 8.336 \\
Denmark & - & - & - \\
Germany & - & - & - \\
Estonia & $4.138,66$ & 61,38 & $7.834,2$ \\
Ireland & 2.416 & - & 933 \\
Greece & - & - & - \\
Spain & 196,12 & $2.393,25$ & $14.770,46$
\end{tabular}




\begin{tabular}{cccc} 
Country & State property & $\begin{array}{c}\text { Other public } \\
\text { entities }\end{array}$ & Private property \\
\hline France & $4.629,66$ & $6.495,69$ & 37.029 \\
Italy & - & - & - \\
Cyprus & 8,96 & 0,47 & 1,53 \\
Latvia & - & - & - \\
Lithuania & 3.393 & - & 3.589 \\
Luxembourg & - & - & - \\
Hungary & $3.666,92$ & 31,72 & $2.157,37$ \\
Malta & - & - & - \\
Netherlands & 510 & 196,2 & 601,6 \\
Austria & $1.620,99$ & - & $17.571,07$ \\
Poland & $43.553,85$ & 831,59 & $2.334,09$ \\
Portugal & 450,42 & 133,69 & $13.460,4$ \\
Romania & $\mathbf{8 . 6 1 0 , 0 1}$ & $\mathbf{3 . 1 7 8 , 2 8}$ & $4.200,91$ \\
Slovenia & $1.515,6$ & 44,8 & $3.478,88$ \\
Slovakia & $5.084,4$ & 812,93 & $3.705,53$ \\
Finland & $5.442,18$ & - & $62.846,99$ \\
Sweden & - & - & - \\
\hline
\end{tabular}

Source: Authors' processing based on Eurostat data

If we look at the data on forest exploitation (Table 4) and the number of workers of the state-owned company Romsilva (Table 5), we notice that over 16 thousand people are involved in harvesting over 8,500 thousand cubic meters of raw wood, approximately 530 cubic meters/employee, at the level of 2018. In Finland, in the state company Metsähallitus work a little over 1 thousand people who harvest over 5,400 thousand $\mathrm{m} 3$, approximately $5,400 \mathrm{~m} 3 /$ employee, ten times more than a worker from Romania. Moreover, the same company in Finland manages 5.1 million hectares of forest with only 1,000 employees, while in Romania, Romsilva manages just over 3 million hectares of forest with 16,000 employees. Over $37 \%$ of the forestry and logging workforce is incorporated into the Romsilva RA National Company while in Finland only $7 \%$ is employed in the Metsähallitus. 

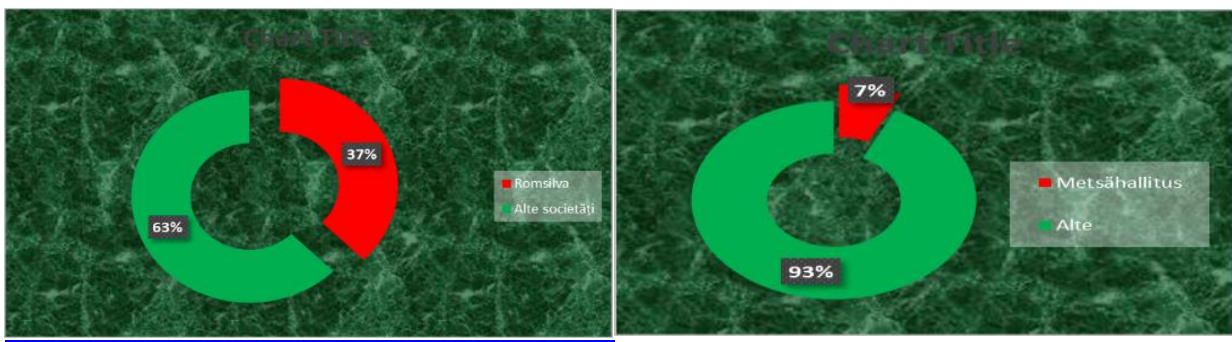

Figure 3. Employment in the forest industry and in the forest sector (\%), Romsilva - Romania (left), Metsähallitus - Finland (right)

Source: Authors' processing based on Eurostat data

Table 5. Romsilva - financial data 2010-2018

\begin{tabular}{ccccc} 
Year & $\begin{array}{c}\text { Average } \\
\text { number of } \\
\text { employees }\end{array}$ & Total salaries & Production sold & Net income \\
\hline 2010 & 19.131 & 540.406 .527 & 1.102 .878 .565 & 1.024 .431 \\
2011 & 18.601 & 581.572 .345 & 1.203 .649 .031 & 21.452 .998 \\
2012 & 18.256 & 614.246 .499 & 1.297 .203 .053 & 58.929 .997 \\
2013 & 17.934 & 655.721 .505 & 1.440 .002 .194 & 71.550 .512 \\
2014 & 16.706 & 687.485 .119 & 1.513 .725 .059 & 103.086 .431 \\
2015 & 16.488 & 715.073 .305 & 1.587 .801 .569 & 157.022 .787 \\
2016 & 16.318 & 837.911 .578 & 1.691 .562 .222 & 210.168 .056 \\
2017 & 16.246 & 994.668 .019 & 1.963 .589 .567 & 248.869 .080 \\
2018 & 16.485 & 1.242 .710 .821 & 2.296 .999 .905 & 178.236 .767 \\
\hline
\end{tabular}

Source: Data processing of authors [15]

Despite the technological advances registered in the field, in Romania, the types of forest measurements have not been changed more, in the last 40 years. Romanian foresters consider the same physical characteristics as their previous generations: the height of the tree, the diameter of the tree, the conical points on the tree stem, the diameter of the crown and any defects or rot. This confirms the need to use such a large number of employees in the state-owned company, compared to how many employees are involved the similar company in Finland.

\section{Discussions}

As in any other field, in the forestry sector are certain limitations that affect the sustainable management of forests with a major impact on the economic, social and environmental factors. These limitations target illegal 
forestry activities due to lack of land property recognition and institutionalized corruption. Illegal logging is a global problem and affects many forested countries. It is estimated that the damage resulting from illegal exploitation is between 51 and 152 billion USD, globally [11]. The demand for timber is so high that illegal logging will remain a major concern for the future of forest resources, unless constant global efforts are made to control it [9].

In this respect, the assessment of the forestry workforce must also take into account informal operators (small and medium-sized enterprises) operating in local markets which, due to lack of resources, may involve human resources in illegal activities.

The same behavior is specific to Romania, in the forestry field being employed 216.2 thousand people and the estimation indicate a much larger population that depends directly on the forest resource.

\section{Conclusions}

The labor force in the Romanian forestry sector is part of the trajectory registered by the European Union, as a whole, because many of the member countries are still oriented on the traditional methods of administration, harvesting and processing. However, global trends are aimed at reducing the number of people employed as a result of the impact of new technologies, and developments. Sweden and Finland show that this is also possible in the forestry sector.

According to the level of education, the analysis of the workforce structure showes that the sector still includes a lower-skilled workforce. This category is the most vulnerable, being the first category that will be affected, when we talk about new technologies, because technological developments need employees with superior capabilities and skills.

From the point of view of the evolutions registered by the female labor force in the forestry sector, it continues to be kept at a low level, due to the particularities of these activities, Romania being on the same level with the European average. International development requirements and trends require an increase in the number of women in employment, in order to eliminate gender differences. This aspect can be implemented, given that the differences between the male and female employment rates have been reduced, at European level, especially if we take into account the fact that sustainable activity in the forestry sector implies the extension of the benefits offered by forest. In this regard, the female workforce can be successfully involved in ecosystem services. 
Looking at global trends, the labor force is vulnerable and exposed to uncertainties that do not provide enough concrete elements of analysis to be able to make future estimates and forecasts.

Studies launch the idea that new technologies are creating jobs, but equally, jobs are being lost by those who are not ready to embrace the novelty. Here, the role of education and professional reconversion is essential. Moreover, those who migrate from the category of employed people to the category of socially assisted people, certainly migrate to poverty.

Returning to the forestry sector in Romania, the increase in the number of employed people based on the quantitative increase of jobs due to the gross exploitation of resources will slow down by adopting new technologies, reducing the consumption of natural resources and as an effect of economic shocks caused by pandemics and measures that have been taken in this regard.

Romania must adopt those appropriate measures in order to help incorporation of the labor released from the forestry sector of resource exploitation into adjacent sustainable activities.

They will face those countries that have agreed to provide for resilience measures in advance, as well as those countries that are financially strong.

\section{References}

[1] Andersson E, Lidestav G. (2014). Gendered resource access and utilisation in swedish family farming. Land. 2014;3:188-203.

https://doi.org/10.3390/land3010188

[2] Angelsen A, Jagger P, Babigumira R, Belcher B, Hogarth NJ, Bauch S, Börner J, Smith-Hall C, Wunder S. Environmental income and rural livelihoods: a global-comparative analysis. World Development. 2014;64:S12-S28.

[3] FAO. State of the World's Forests [Internet]. 2014. Rome. Available from: http://www.fao.org/3/a-i3710e.pdf

[4] FAO. State of the World's Forests [Internet]. 2018. Rome. Available from: http://www.fao.org/3/I9535EN/i9535en.pdf

[5] FAO. State of the World's Forests [Internet]. 2020. Rome. Available from: http://www.fao.org/forest-resources-assessment/2020

[6] Forest Europe. Home page [online]. 2019. Zvolen, Slovakia.

[7] Garnett ST, Burgess ND, Fa JE, Fernández-Llamazares Á, Molnár Z, Robinson CJ, Watson JE. et al. A spatial overview of the global importance 
of indigenous lands for conservation. Nature Sustainability. 2018;1(7):369_ 374.

[8] Hegetschweiler KT, de Vries S, Arnberger A, Bell S, Brennan M, Siter N, Olafsson AS, Voigt A, Hunziker M. Linking demand and supply factors in identifying cultural ecosystem services of urban green infrastructures: A review of European studies. Urban Forestry and Urban Greening. 2017;21:48-59. https://doi.org/10.1016/j.ufug.2016.11.002

[9] Hoare A. Tackling illegal logging and the related trade: what progress and where next? Chatham House Report. London: Chatham House, The Royal Institute of International Affairs; 2015.

[10] Mörald E, Sandstrom C, Nordin A. Forest, Governance and Management Across Time. Developing a new social contract. London/New York: Routledge; 2017

[11] Nellemann C, Henriksen R, Kreilhuber A, Stewart D, Kotsovou M, Raxter P, Mrema E, Barrat S. (eds.). The rise of environmental crime: A growing threat to natural resources peace, development and security. Nairobi, UNEP, and Oslo: Norwegian Center for Global Analyses (RHIPTO); 2016.

[12] Newton P, Miller DC, Byenkya MAA, Agrawal A. Who are forest-dependent people? A taxonomy to aid livelihood and land use decision-making in forested regions. Land Use Policy. 2016;57:388-395.

[13] Paumgarten F, Locatelli B, Witkowski ETF. Wild foods: safety net or poverty trap? A South African case study. Human Ecology. 2018;46(2):183195.

[14] Pülzl H, Kleinschmit D, Arts B. Bioeconomy - an emerging meta-discourse affecting forest discourses? Scand. J. Forest Res. 2014;29:386-393. https://doi.org/10. 1080/02827581.2014.920044.

[15] Romsilva, Buget si situatii financiare [Internet]. 2010-20019, Available from: http://www.rosilva.ro/rnp/buget si situatii financiare p 55.htm 